\title{
Experimental Static Load Test of Concrete Industrial Floor Model
}

\author{
Petr Mynarcik* and Martina Janulikova \\ Department of Structures, Faculty of Civil Engineering, VSB-Technical University Ostrava, Ludvika Podeste 1875/17, 708 33, \\ Ostrava - Poruba, Czech Republic \\ *Corresponding author
}

\begin{abstract}
This article is focused on problematic of interaction between foundation structure and subsoil. This phenomenon is observed through the experimental measurements on the large scale models and these experiments are realized on testing device located at the Faculty of Civil Engineering, VSB-Technical University of Ostrava. In this contribution are presented experimental results of static load test implemented on the concrete industrial floor model.
\end{abstract}

Keywords-subsidence of foundation slabs; concrete foundation structures;soil-structure interaction; contact stress

\section{INTRODUCTION}

Interaction between concrete structure and subsoil is one of the main research direction at the Faculty of Civil Engineering, VŠB - Technical university of Ostrava [1]-[3]. Actually, research is focused on experimental testing of different types of industrial floors. For experimental static load test was concreted model of plain concrete industrial floor. The experimental model was designed as a part of plain concrete industrial floor without reinforcement and static load test was conceived as a simulation of loading by base plate of heavy rack. The experiment served to a better understanding and possible improvement of these technologies from the perspective of interaction with the subsoil.

\section{CONCRETE FloOR MODEL DESCRIPTION}

The experimental model simulated a part of plain concrete industrial floor. The elementary dimensions of the experimental model were $2000 \times 2000 \times 200 \mathrm{~mm}$. The concrete type C35/45 $\mathrm{XF} 1$ was used for concreting to the steel formwork.

\section{SUBSOIL CHARACTERISTICS DESCRIPTION}

The experimental model was settled on homogenized clay layer. Clay layer thickness was $1000 \mathrm{~mm}$ and was compacted on prime clay subsoil without greensward [4]. The subsoil characteristics were determined by standard geotechnical measurements. The sliding joint was made from combination of PVC foil and geotextile [5], [7], [9]. The experimental model was situated in outdoor testing device STAND [6].

Subsoil characteristics:

- Subsoil consists of loess loam with F4 consistency.

- $\quad$ Thickness of subsoil layer is about 5 meters.
- Volumetric weight of soil $\gamma=18,5 \mathrm{kN} . \mathrm{m}^{-3}$.

- Poisson coefficient $v=0,35$.

- $\quad$ Static Young's modulus $\mathrm{E}_{\mathrm{DEF}}=10 \mathrm{MPa}$.

\section{Testing DeVICES AND MEASUREMENTS DESCRIPTION}

Experiment was realized on the outdoor testing device "STAND". This device is consists of two frames and crossbeams. Crossbeams enable variability of the press machine location. The frames are anchored with screws into the steel grate based in the reinforced concrete strip foundations. The construction is anchored with $4 \mathrm{~m}$ long micropiles. The maximal possible vertical load is $1000 \mathrm{kN}$ [6]. The experimental static loading test on a plain concrete industrial floor model was the assembly of a set of measurements. Measurement gauges completed the experimental measurement line [1], [3].

The experimental measurement line:

- 14 potentiometric position sensors for measurement of vertical deformations (subsidence).

- Built-in pressure sensor for measurement of the vertical load

- 4 strain gauges for measurement on the surface of the slab - tension of concrete.

- 4 strain gauges for measurement inside the experimental slab - tension of concrete.

- 9 geotechnical pressure cells in different height horizons for measurement of the stress on the interface of the slab and subsoil.

- 8 temperature sensors for measurement of temperature inside and on the surface. 


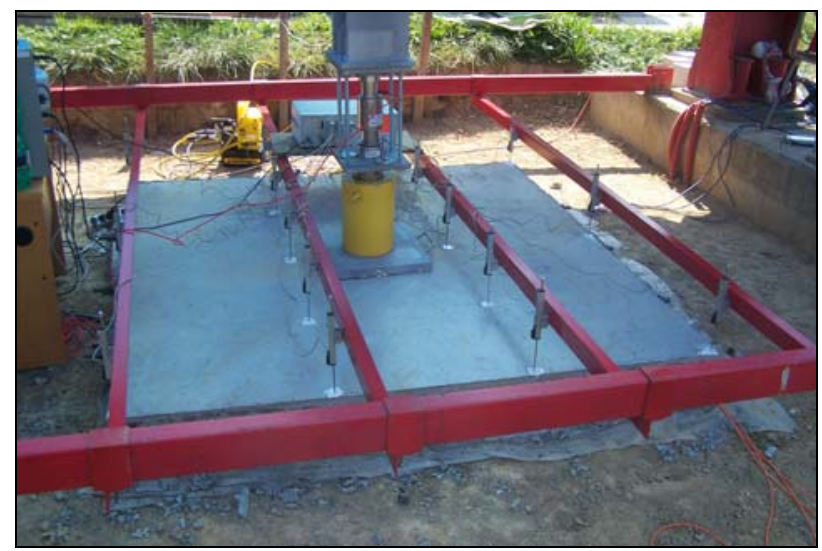

FIGURE I. THE EXPERIMENTAL MEASUREMNT LINE AT WORK.

\section{Measurement Process of ExPERIMENTAL Model SUBSIDENCE}

The vertical load was caused by the high tonnage hydraulic cylinder ENERPAC CLRG. The loaded equipment was placed between the experimental model and the steel extension fixed on STAND. The hydraulic system was equipped with the pressure sensor. Potentiometric position sensors were installed on the surface of concrete floor model. These gauges were connected to the same sensor station with automatic scanning and recording. Shape and size of load area simulated base plate of heavy loaded rack. Dimensions of load area were 400 x 400 $\mathrm{mm}$. Fixed interval of loading $-80 \mathrm{kN} / 30 \mathrm{~min}$ was chosen for this experimental testing. Vertical deformations were measured and recorded by the set of 16 potentiometers AHLBORN. FWA100T. Potentiometers were connected with the sensor station ALMEMO 5590. The station was programmed to automatic scanning and recording measured values. Schematic plan of sensors are displayed on Figure 2.

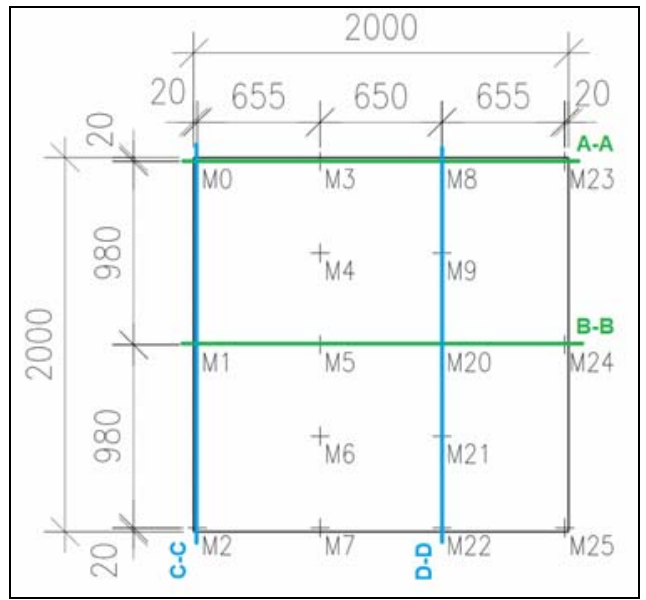

FIGURE II. SCHEMATIC PLAN OF POTENTIOMETRIC SENSORS POSIITION.

\section{MEASUREMENT ResultS}

Potentiometric sensors situated on non-contact surface recorded vertical deformations in particular positions.
Graphical results of vertical deformations - subsidence, are visualized on Figures 3-4. The development of vertical deformation in the edge area of experimental model is represented by cross-section A-A and C-C. From the graphs of edge area the lifting in corners of the experimental model is noticeable. The development of subsidence in the central area of experimental model is represented by cross-section B-B and D-D. These graphs showed centralized subsidence in the central part of experimental model. The creation and progression of punching shear is also noticeable from graphs of cross-sections B-B and D-D.

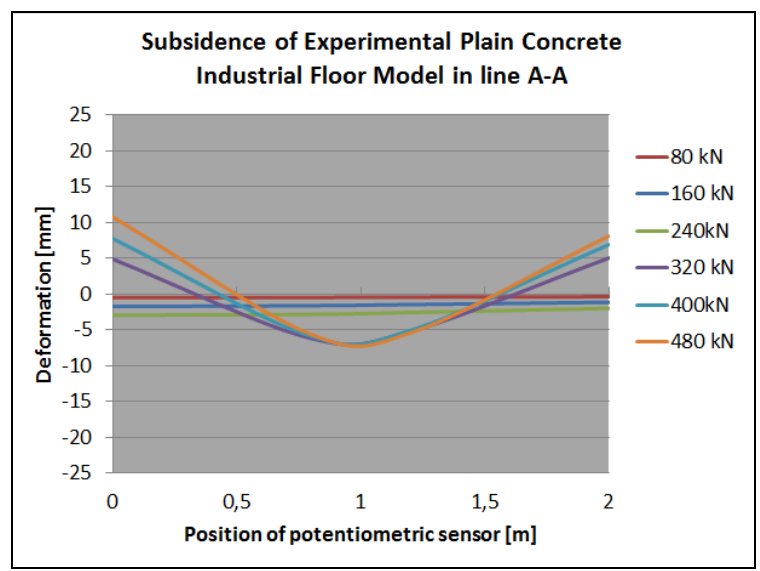

FIGURE III. THE VERTICALA DEFORMATIONS IN CROSS-SECTION A-A (POTENTIOMETRIC SENSORS M0, M3, M8, M23).

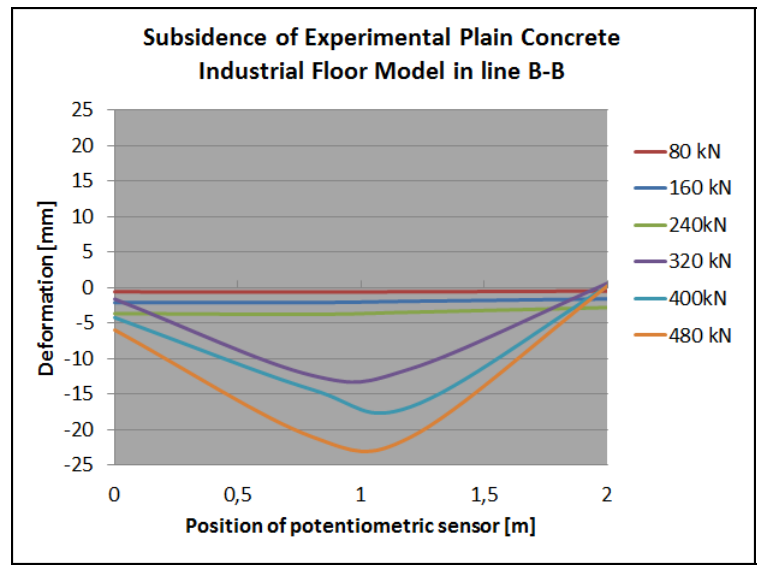

FIGURE IV. THE VERTICALA DEFORMATIONS IN CROSS-SECTION B-B (POTENTIOMETRIC SENSORS M1, M5, M20, M24). 


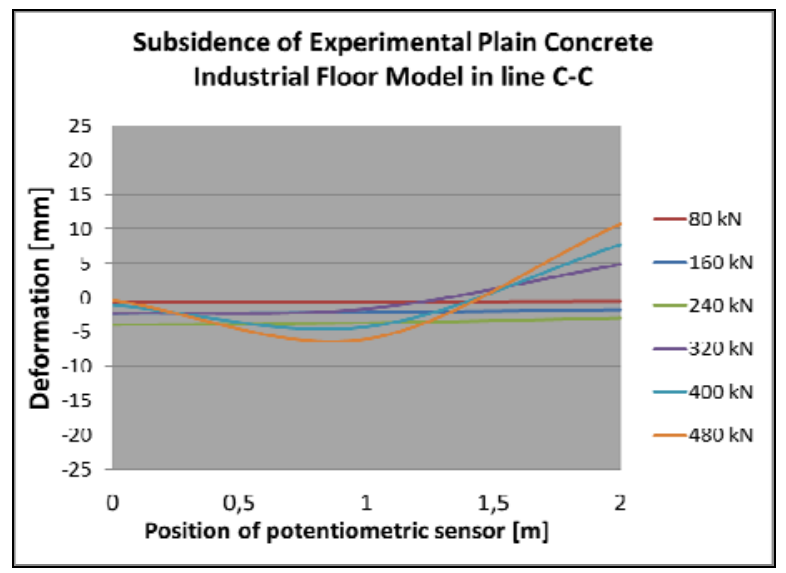

FIGURE V. THE VERTICALA DEFORMATIONS IN CROSS-SECTION C-C (POTENTIOMETRIC SENSORS M0, M1, M2).

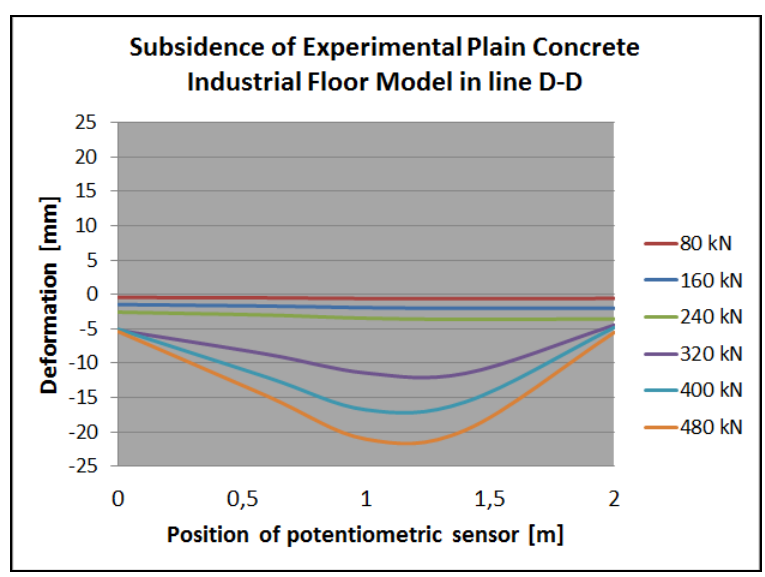

FIGURE VI. THE VERTICALA DEFORMATIONS IN CROSS-SECTION D-D (POTENTIOMETRIC SENSORS M8, M9, M20, M22).

\section{MEASUREMENT ReSultS - Major CRACK DISTRIBUTION}

First significant cracks were detected after fourth loading step. Major seven cracks were observed on the lateral side of the experimental model. After every loading step - thickness of cracks were increased. Maximal values of thickness of partial crack after last loading step are sorted in Table 1. Positions of crack are visualized on schematic plan Figure 7.

TABLE I. THE MAXIMAL CRACK THICKNESS.

\begin{tabular}{|c|c|}
\multicolumn{1}{c|}{} & Maximal Crack thickness \\
\hline Crack no. 1 & $4,50 \mathrm{~mm}$ \\
\hline Crack no. 2 & $4,50 \mathrm{~mm}$ \\
\hline Crack no. 3 & $3,50 \mathrm{~mm}$ \\
\hline Crack no. 4 & $4,00 \mathrm{~mm}$ \\
\hline Crack no. 5 & $10,00 \mathrm{~mm}$ \\
\hline Crack no. 6 & $10,00 \mathrm{~mm}$ \\
\hline Crack no. 7 & $4,00 \mathrm{~mm}$ \\
\hline
\end{tabular}

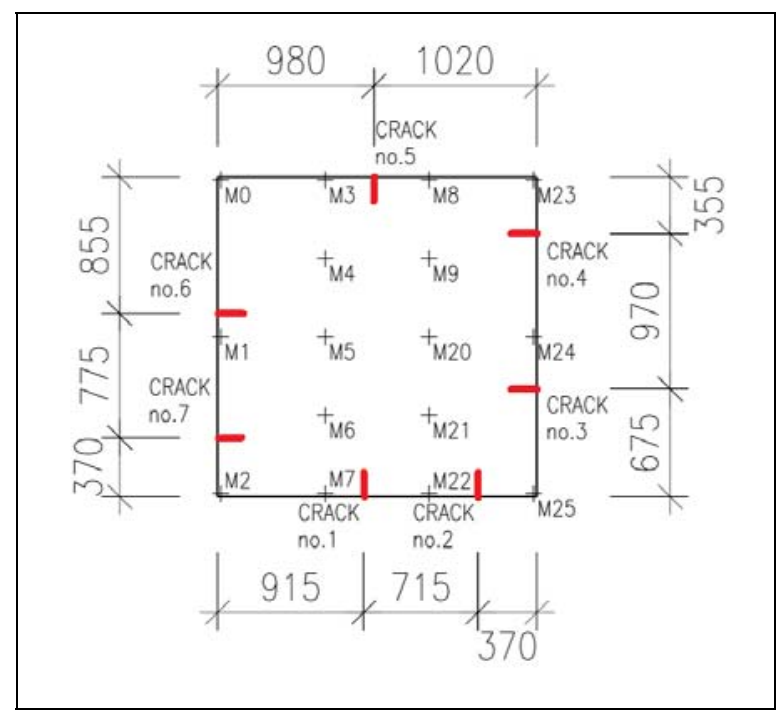

FIGURE VII. SCHEMATIC PLAN OF MAJOR CRACK DISTRIBUTION.

\section{CONCLUSION}

Experimental plain concrete industrial floor model resist the loads exerted after six load cycles and induced maximal load level $480 \mathrm{kN}$. First significant cracks were detected after fourth loading step. After sixth loading step were detected first signs of punching share. Experiment was ended in moment, when the model was strongly damaged by punching share. This experiment bring many information about influence of punching share phenomenon on slab-on-ground. Measured data will serve for creating of numerical model by FEM (finite element method) [10]-[12].

\section{ACKNOWLEDGMENT}

The works were supported from sources for the conceptual development of research, development and innovations for 2015 at the VSB-Technical University of Ostrava, which were granted by the Ministry of Education, Youths and Sports of the Czech Republic.

\section{REFERENCES}

[1] P. Mynarcik,. Core Sampling for Fiber Concrete Constructions Context Between Quantity of Core Samples and Evaluation of Fiber Concrete Characteristics. Procedia Engineering [online]. 2015, 114: 493499. DOI: 10.1016/j.proeng.2015.08.097.

[2] P. Mynarcik, The Subsidence Analysis of Experimental Post-tensioned Concrete Slab Model in the Course of the Static Load Test, Applied Mechanics and Materials, vol. 744 - 746, pp. 1556-1559 (4 p), Trans Tech Publications, Switzerland, doi:10.4028/www.scientific.net/AMM. $744-746.1556,2015$.

[3] P. Mynarcik, Measurement processes and destructive testing of fibre concrete foundation slab pattern, Advanced Material Research, vol. 1020, pp. 221-226 (6 p), Trans Tech Publications, Switzerland, ISSN (Online) 1662-8985, ISSN (Print) 1022-6680, DOI: 10.4028/www.scientific.net/AMR.1020.221, 2014.

[4] R. Cajka, R. Fojtik, Development of Temperature and Stress during Foundation Slab Concreting of National Supercomputer Centre IT4, Procedia Engineering, vol. 65, 2013, pp. 230-235 (6 p), ISSN 1877-7058, doi: 10.1016/j.proeng.2013.09.035. 
[5] R. Cajka, K. Burkovic, V. Buchta, Foundation Slab in Interaction with Subsoil, Advanced Materials Research, Volumes 838-841, pp. 375-380 (6 p), Trans Tech Publications, Switzerland, doi:10.4028/www.scientific.net/AMR.838-841.375, 2014.

[6] M. Janulikova, R. Cajka, P. Mateckova, V. Buchta, Laboratory Testing of Asphalt Belts Rheological Properties Exposed to Shear Loads, Transactions of the VŠB - Technical University of Ostrava, Civil Engineering Series, vol. XII, iss. 2, pp. 59-66 (8 p), ISSN (Online) 1804-4824, ISSN (Print) 1213-1962, doi: 10.2478/v10160-012-0018-2, 2013.

[7] R. Cajka, V. Krivy, D. Sekanina, Design and Development of a Testing Device for Experimental Measurements of Foundation Slabs on the Subsoil, Transactions of the VŠB - Technical University of Ostrava, Civil Engineering Series, vol. XI, iss. 1, pp. 1-6 (6 p), ISSN (Online)1804-4824, ISBN 978-80-248-2332-4, doi: 10.2478/v10160011-0002-2, 2011.

[8] M. Janulikova, M. Stara, Multi-layer Rheological Sliding Joint in the Foundation Structures, Transactions of the VŠB - Technical University of Ostrava, Civil Engineering Series, vol. XIII, iss. 2, pp. 41-46 (6 p), ISSN (Online) 1804-4824, ISSN (Print) 1213-1962, doi: 10.2478/tvsb2013-0008, 2013.

[9] M. Janulikova, P. Mynarcik, Modern Sliding Joints in Foundations of Concrete and Masonry Structures, International Journal of Mechanics, vol.8, iss.1, United States: North Atlantic University Union, pp. 184 189 (6 p), ISSN 1998-4448, 2014.

[10] M. Janulikova, M. Stara, P. Mynarcik, Sliding Joint from Traditional Asphalt Belts, Advanced Material Research, vol. 1020, pp. 335-340 (6 p), Trans Tech Publications, Switzerland, ISSN (Online) 1662-8985, ISSN (Print) 1022-6680, doi: 10.4028/www.scientific.net/AMR.1020.335, 201-4

[11] R. Cajka, Analytical derivation of friction parameters for FEM calculation of the state of stress in foundation structures on undermined territories, Acta Montanistica Slovaca, vol. 18, iss. 4, pp. 254-261 (8 p), ISSN: 13351788, 2013.

[12] J. Labudkova, R. Cajka, Comparsion of Measured Displacement of the Plate in Interaction with the Subsoil and the Results of 3D Numerical Model, Advanced Material Research, vol. 1020, pp. 204-209 (6 p), Trans Tech Publications, Switzerland, ISSN (Online) 1662-8985, ISSN (Print) 1022-6680, DOI: 10.4028/www.scientific.net/AMR.1020.204, 2014.

[13] J. Labudkova, R. Cajka, Comparison of the Results from Analysis of Nonlinear Homogeneous and Nonlinear Inhomogeneous Half-Space. Procedia Engineering [online]. 2015, 114: 522-529. DOI: 10.1016/j.proeng.2015.08.10 